\title{
NEOICHNOLOGY OF THE SEAWARD SIDE OF PEIXE LAGOON IN MOSTARDAS, SOUTHERNMOST BRAZIL: THE PSILONICHNUS ICHNOCOENOSIS REVISITED
}

\author{
RENATA GUIMARÃES NETTO \\ PPGeo UNISINOS, Av. Unisinos, 950, 93022-000, São Leopoldo, RS.nettorg @ unisinos.br \\ MARCELO ENGELKE GRANGEIRO \\ Deceased in June, 2005
}

\begin{abstract}
This paper characterizes the modern Psilonichnus ichnocoenosis present in the seaward side of Peixe Lagoon (southernmost Brazil) and discusses its preservation potential in the fossil record and its (paleo)environmental and stratigraphic significances. This ichnofauna occurs in exposed softgrounds and stiffgrounds of the backshore and backbarrier environments associated with the channel mouth area of the lagoon. The burrow assemblage is composed of Y-and J-shaped dwelling burrows and trackways of grapsid crabs (Chasmagnatus granulata), fiddler crabs (Uca uruguayensis), and ocypodid crabs (Ocypode quadrata), tracks and trackways of scarab beetles, birds, and small lizards, horizontal, randomly branched, shallow feeding burrows of mole crickets, dwelling burrows of small rodents and ant nests. As a natural park, most of the natural environmental conditions that support the establishment of such an ichnocoenosis are preserved in the study area, favoring its use as a modern analogue to the ancient Psilonichnus Ichnofacies. Thus, original concepts developed after the first record of the Psilonichnus ichnocoenosis in modern environments, which supported the construction of the Psilonichnus Ichnofacies paradigm, are revisited herein and some premises are reinforced. Possible stratigraphic scenarios are also estimated, allowing the inference that the best preservation of the Psilonichnus Ichnofacies occurs during the establishment of transgressive system tracts.
\end{abstract}

Key words: Psilonichnus ichnocoenosis, Psilonichnus Ichnofacies, crab burrows, marginal marine settings, Peixe Lagoon.

RESUMO - Este trabalho caracteriza a icnonocenose moderna de Psilonichnus presente na porção marinha da lagoa do Peixe (extremo sul do Brasil) e discute seu potencial de preservação no registro fóssil e seu significado (paleo)ambiental e estratigráfico. A icnofauna analisada ocorre em substratos moles e em substratos compactados plásticos de ambientes de antepraia e atrás da barreira eólica associados à área de desembocadura do canal principal que alimenta a lagoa. A assembléia é composta por trilhas e escavações de moradia em forma de Y e J de caranguejos (Chasmagnatus granulata, Uca uruguayensis e Ocypode quadrata), pegadas e trilhas de aves, pequenos lagartos, besouros escarabeídeos, escavações horizontais, irregularmente ramificadas, rasas, feitas por grilotalpídeos em busca de alimento, galerias de pequenos roedores e ninhos de formigas. Por ser um parque natural, as condições ambientais vigentes na lagoa do Peixe são muito próximas das de ambientes intocados, o que favorece ao estudo da icnocenose de Psilonichnus ali presente como análogo moderno da Icnofácies Psilonichnus. Assim, os conceitos originais, formulados a partir do primeiro registro da icnocenose de Psilonichnus em ambientes modernos - e que serviram de base para a construção do paradigma que rege a Icnofácies Psilonichnus -, são aqui revisitados e algumas premissas, reforçadas. A análise de possíveis cenários estratigráficos permite inferir que a melhor preservação da Icnofácies Psilonichnus se dê durante o estabelecimento de tratos de sistemas transgressivos.

Palavras-chave: icnocenose de Psilonichnus, Icnofácies Psilonichnus, escavações de caranguejos, ambientes marginais marinhos, lagoa do Peixe.

\section{INTRODUCTION}

Although being encouraged during the 1970s and 1980s, neoichnological studies are still less extensive than those focused on paleoichnological record. Also, most of the studies on modern biogenic sedimentary structures are related to coastal environments, such as those conducted by Hertwek (1972), Howard \& Dorjes (1972), Basan \& Frey (1977), and Frey \& Pemberton (1987) on the Georgia coast (USA), Frey et al. (1987) in the Yellow Sea tidal flats, Curran \& White (1991), White \& Curran (1993), and Curran (1994) on San Salvador Island (Bahamas), Gingras et al. (1999, 2000, 2002, 2004) in 
Willapa Bay (USA), De (2000) in the coastal Ganges Delta Complex (India), Grangeiro \& Netto (2003) in Peixe Lagoon (southernmost Brazil), and Dashtgard \& Gingras (2005) and Hauck et al. (2009) on New Brunswick coast (Canada), among others.

The Psilonichnus Ichnocoenosis, as defined by Frey \& Pemberton (1987), occupies supralittoral to upper littoral substrates, deposited under moderate to low-energy marine and (or) aeolian conditions, and subject to modification by torrential rains or storm surges. Substrates are often composed of well-sorted, variably laminated to crossstratified sand, to root- and burrow-mottled, poorly sorted sand or muddy sand. They characterize coastal settings, typically represented by beach backshore and dunes, but also by washover fans, supratidal flats, and tidal inlets, intergradational with the maritime terrestrial zone (MacEachern, 2001). Vertical, irregularly J-, Y-, or U-shaped shafts, some of them with bulbous basal cells, are the predominant biogenic structures, representing ocypodid crab or thalassinoidean shrimp-dwelling burrows, most of them assigned to the Psilonichnus ichnogenus (Fürsich, 1981; Frey et al., 1984; Nesbitt \& Campbell, 2006). Invertebrate and vertebrate crawling and foraging traces or superficial tunnels, as well as microbial mats, vertebrate tracks and coprolites can be locally present. The diversity of invertebrates is low, being mostly predators or scavengers, while vertebrates could be locally more diverse, being predominantly predators or herbivores. In pre-Cretaceous units, crab-like dwelling burrows may be absent (MacEachern, 2001).

Pemberton \& Frey (1987) interpreted this ichnocoenosis as representative of the Psilonichnus Ichnofacies, which represents a mixture of marine, quasimarine and nonmarine conditions. However, the common occurrence of Psilonichnus upsilon in Pleistocene Bahamian backshore deposits popularized the Psilonichnus Ichnofacies as a backshore indicator (e.g. Curran \& White, 1991; Gibert \& Martinell, 1998; MacEachern, 2001; Nesbitt \& Campbell, 2006), although it has a broader facies distribution in modern coastal settings. Although Frey et al. (1990) had recognized the Psilonichnus Ichnocoenosis as an archetypical ichnofacies, the non observance of a long temporal distribution in geological record supports the concern about its validity (Bromley \& Asgaard, 1991; Gibert \& Martinell, 1998) and its spatial distribution. Therefore, the aim of this paper is twofold: to revisit the Psilonichnus Ichnocoenosis, based on its occurrence in the seaward side of Peixe Lagoon, and to review its distribution in the marginal marine settings, in light of the predominant ecologic and sedimentologic aspects of the study area.

\section{MATERIAL AND METHODS}

This study was based on periodic visits to the channel mouth area of Peixe Lagoon between 1999 and 2002, and sporadic visits from 2003 to 2008, with the objective of analyzing the morphological and environmental aspects of the present biogenic sedimentary structures, identifying their producers, and understanding their behavior when interacting with the substrate. As the study area is part of a national park, a research license was required. The periodic visits occurred every two months and lasted three days each time, and the same study spots were systematically visited. The biogenic sedimentary structures were observed, their external morphology analyzed. The Y-shaped burrows made by Chasmagnathus granulata were usually counted, and differences in sizes and morphology of burrow entrances, the number of individuals per burrow, sex and behavior were considered, but no systematic statistics calculated. Data from the lagoon benthic fauna and terrestrial biota living in or around the lagoon settings, the chemical-physical aspects of the lagoon and the surrounding substrates, geomorphological and geographical characteristics, sediments and sedimentary facies were also obtained and analyzed.

Burrow architectures were accessed by casting, using the uncolored acrylic resin RPI AROTEC. Water salinity was systematically measured, from the lagoon and from the bottom of the crab burrows, to access the salinity gradient and its fluctuations in the study area. Biota were not collected, but identified.

Sedimentological data (granulometry, presence/absence of matrix, grain selection and mineral composition, physical and biogenic sedimentary structures) acquisition consisted of four SE/NW oriented transects which crosscut four NE/ SW oriented transects in the study area.

\section{GEOMORPHOLOGICAL AND SEDIMENTARY SETTING}

\section{Geomorphological and sedimentary setting}

Peixe Lagoon is a very shallow, 45-km-long water body oriented NE-SW parallel to the coastline, between Mostardas and Tavares counties, in Rio Grande do Sul State, southernmost Brazil (UTM N 6547000 and 6525000, and UTM E 507000 and 485000, Central Meridian 51W; Figure 1). The lagoon is formed by the waters that flow away from the two main fluvial courses when they get to the depressed area, or by marine waters, during storm surges. Its depth average is $0.5 \mathrm{~m}$, except in the channels, where it can be as much as $4 \mathrm{~m}$. The barrier spit forming its seaward limit is approximately 100 $\mathrm{m}$ wide. Pleistocene sandstones and muddy sandstones of the Lagoon-Barrier System III of Rio Grande do Sul Coastal Plain (PCRS, Villwock et al., 1986) form the lagoon floor.

In the Peixe Lagoon area, PCRS overlies the Pre-Cambrian granitic basement and the Tertiary deposits of Pelotas Basin. To the east, it is bound by the modern aeolian sand dunes and the sea (Figure 2). The west border is a small cliff $(\sim 5 \mathrm{~m}$ high) formed by orange-yellowish quartz sandstones of aeolian origin from the Barrier System III (Villwock, 1984).

The lagoon was formed after the last regressive event that took place in PCRS, when the stream channels were confined by a sand barrier, flooding the adjacent plains and the surrounding shallow depressions (Tomazelli \& Villwock, 2000, Figure 2). A constant supply of aeolian sediment source 


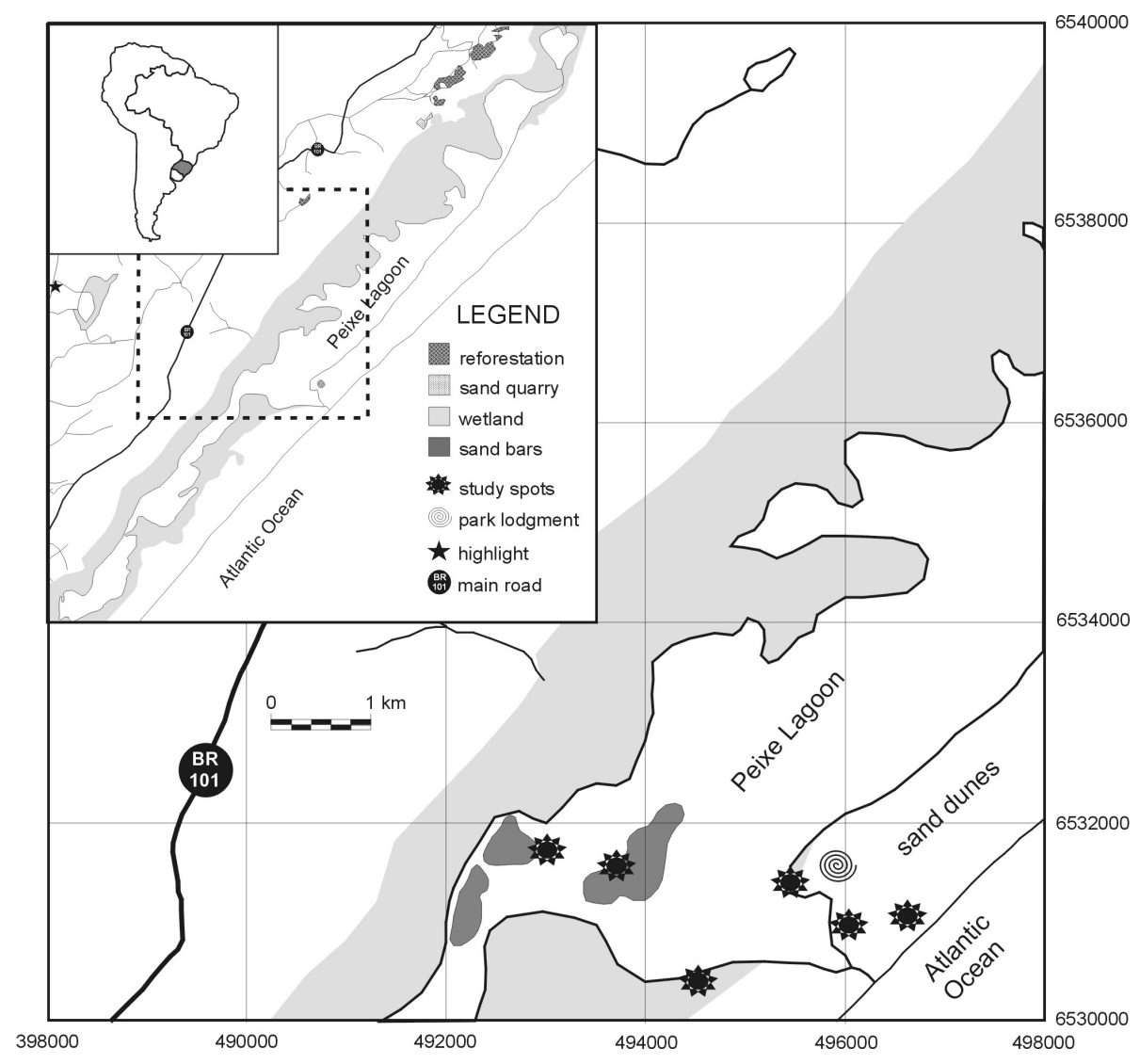

Figure 1. Location map of the study area.

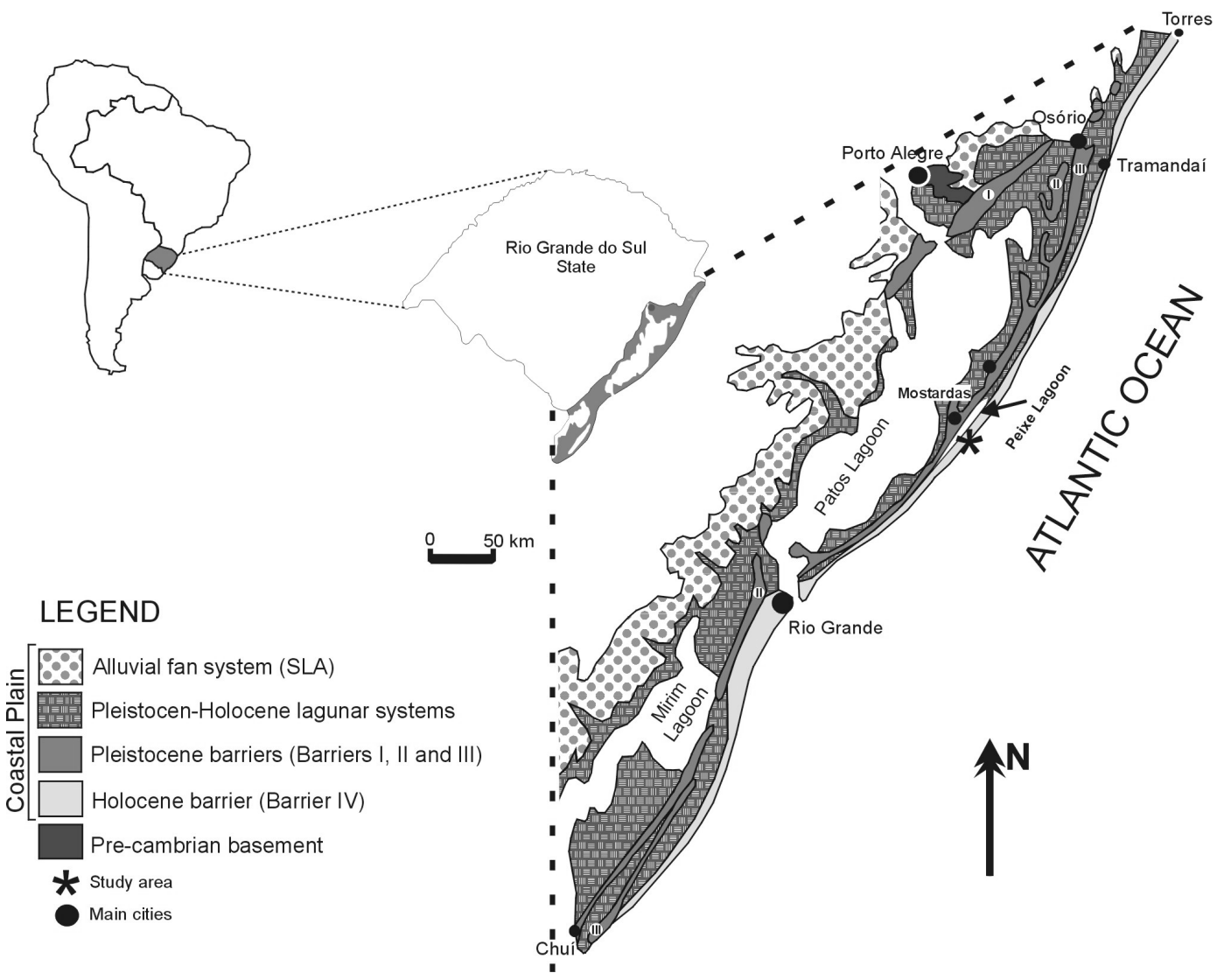

Figure 2. Geological map of the Rio Grande do Sul Coastal Plain (PCRS), showing Peixe Lagoon confined between ancient deposits of Barrier III and modern aeolian deposits of Barrier IV (modified from Tomazelli \& Villwock, 2000). 
maintains the shallow depth of the lagoon. Sporadic storm surges overwash the exposed sand barrier, introducing marine waters into the lagoon and bringing marine organisms with them. Most of these organisms return to the sea when the water level falls, but some stay, forming orphan colonies. During fairweather periods, the barrier is reconstructed and the lagoon becomes confined again. The salinity, in general, diminishes and only organisms tolerant to brackish-water survive. Most of them are burrowers that rework the lagoon floor and the adjacent marginal area. The thickness of water laminae is reduced and a large amount of the lagoon floor is exposed. The salinity gradient of the lagoon seaward-side waters is around 5 to $15 \%$ (mesohaline), being always higher than the inner zones, even when the barrier is up. The main sedimentary deposits observed in the studied area are sandy beaches, aeolian foredune ridge, discrete washover fans on the backshore zone, washover channels, the lagoon floor, as well as vegetated margins (Figure 3 ).

\section{Beach deposits}

Beach deposits are characterized by fine quartz sands forming trough cross-stratification, accumulated as lenticular bodies between the upper shoreface and the foreshore, up to the seaward side of the backshore. Most of the foreshore deposits are frequently exposed, as the tidal gradient is very small $(\sim 0.5 \mathrm{~m})$, being reworked by the wind, which forms small eolic ripples, preserved chiefly in the transition zone to the backshore. Longshore currents resulting from the predominant NE-SW wind direction at Rio Grande do Sul coast commonly rework the sands (Figure 3). Aeolian processes are dominant in subaerial conditions and construct a sand bar in the channel discharge zone, isolating the lagoon from the sea in fairweather periods. Storm surges usually split the bar, generating discrete washover fans and increasing the saline water input into the lagoon. Vertical burrows of pelecypod Donax donax, which characterizes the Skolithos ichnocoenosis in the study area, death marks of jellyfish and trackways of isopod crustaceans are the most frequent biogenic sedimentary structures in the swash line. Ghost crab galleries (Ocypode quadrata) are the dominant burrows in the transition zone to the backshore.

\section{Aeolian foredune deposits}

Yellow, well-sorted, bimodal fine sands forming the actual coastal barchanoid dune ridge and the associated interdune zone, located in the backshore zone, parallel to the shoreline and reaching $5 \mathrm{~m}$ in height (Figures 4A-C). Sand deposition by the wind generates high-angle, tabular cross stratification and sinuous or straight crest asymmetric ripples. The irregular evolution of the dunes produce avalanche sand tongues, and adhesion ripples and tool marks are frequently observed. Channels and ephemeral lakes are usually formed during the storms, mobilizing the sands and creating small fans on the seaward side of the lagoon, which develop into terraces. Tracks and trackways of birds and lizards, horizontal, branched, backfilled burrows of mole crickets (Orthoptera, Grilotalpidae) and beetles (Coleoptera, Scarabeidae), and small horizontal galleries of rodent mammals (Ctenomys ctenomys) are the main biogenic sedimentary structures commonly observed in dune and wet interdune deposits.

\section{Channel deposits}

A main channel oriented NW-SE feeds the lagoon, draining into the sea when the bar is open, being up to $4 \mathrm{~m}$ deep and $200 \mathrm{~m}$ wide (Figures 4D-E). Sand is thrown out into the channels by aeolian aspersion when the depth is less,

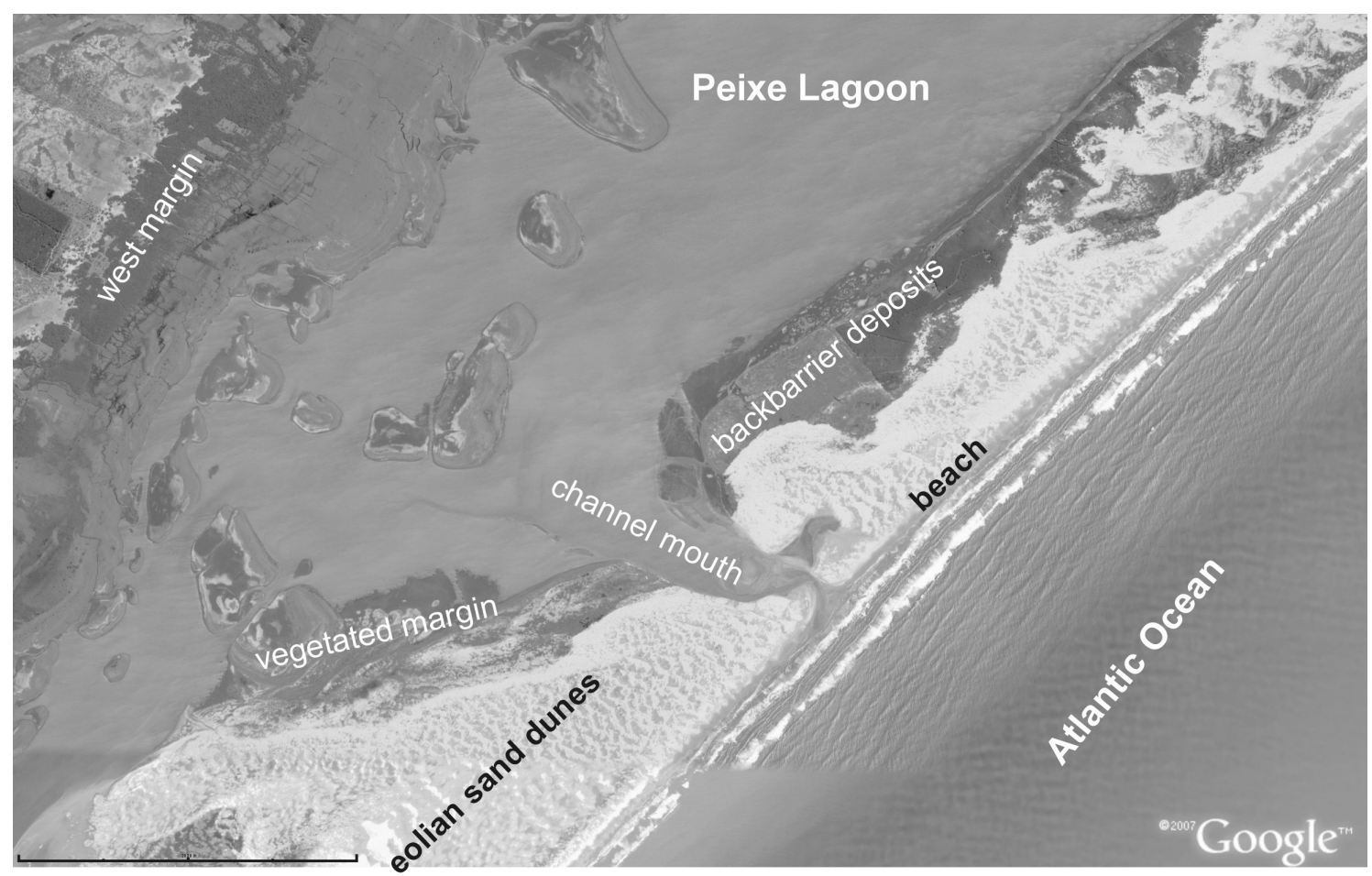

Figure 3. Satellite image from the Peixe Lagoon channel mouth area, showing the main settings in the studied area (image from Google Earth, 2009). 
building barrier islands. Neap tidal currents form straight crest ripples and bidirectional cross stratification when the bar is open. Biogenic sedimentary structures are observed in the exposed channel margin deposits, which bear vertical Y-, Jand U-shaped burrows made by the amphibious crab Chasmagnatus granulata (Y and U) and Uca uruguayensis $(\mathrm{J})$, as well as bird tracks and pelecypod vertical burrows (Tagelus plebeus). Stable channel margins are vegetated by grasses and mangroves.

\section{Lagoon deposits}

The flooded area adjacent to the channels characterizes the lagoon deposits and is composed of organic rich muddy sands (Figure 4F). The lagoon margin is periodically expanded, exposing part of its floor, either due to the bar overflow due to storm surges, or due to low rainfall, in spring and summer times. When exposed, muddy sand softgrounds lose water and give rise to stiffgrounds or, seldom, firmgrounds (Gingras et al., 2000, 2001). Biogenic sedimentary structures inside the lagoon are produced by a low-diversity benthic fauna, composed of mobile and stationary polychaetes, crabs (Callinectes sapidus), pelecypods (T. plebeus), and thalassinidean shrimp, which supply food to migratory birds. Outside the lagoon, the edges are densely reworked by vertical, short Y- and J-burrows of respectively $C$. granulata and $U$. uruguayensis. Tracks and trackways of crabs and birds are also common and old openings of abandoned vertical shafts of polychaetes and $T$. plebeus can be seen when the water laminae is very shallow, almost exposing the lagoon floor.
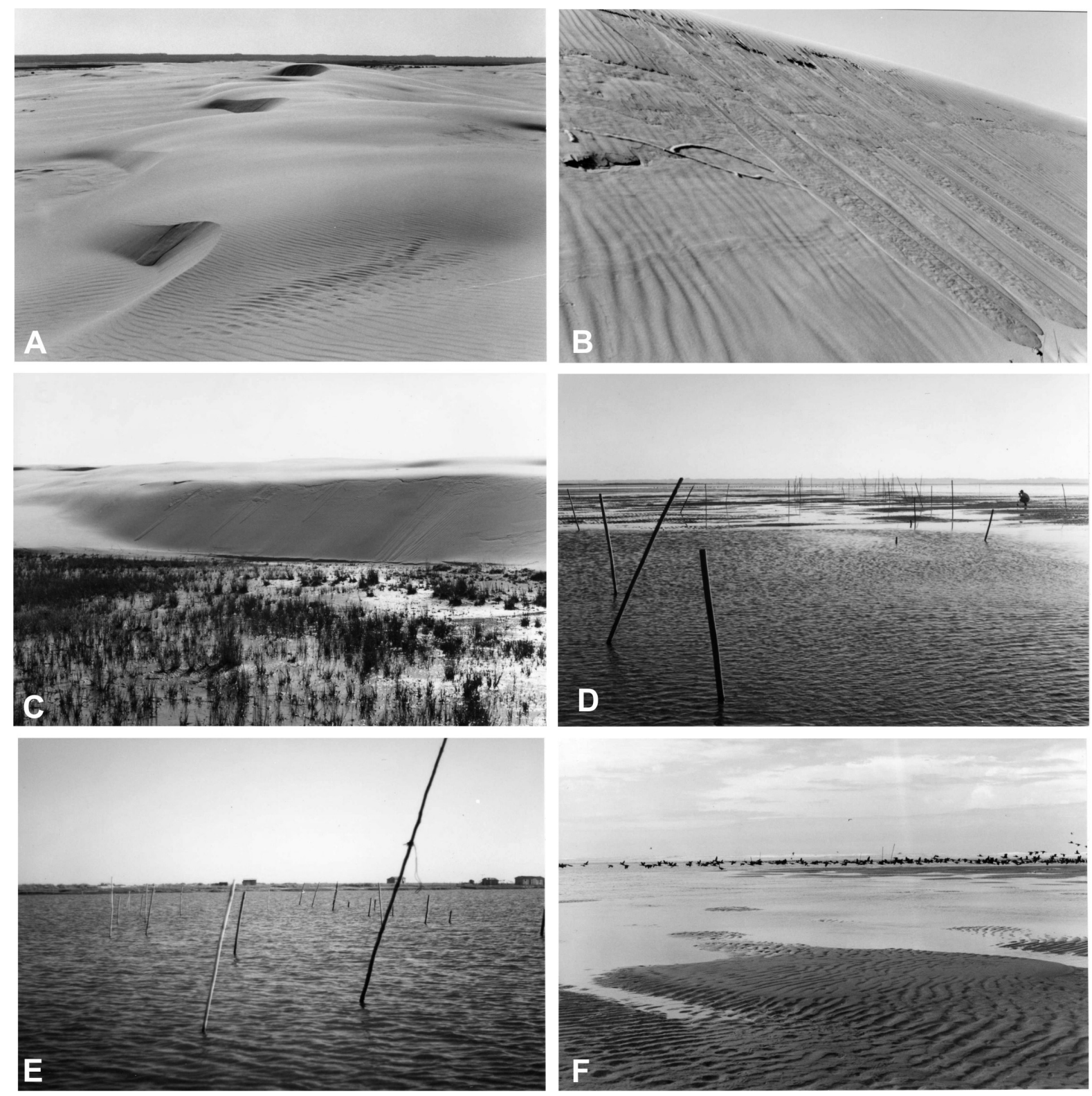

Figure 4. Main sedimentary deposits of the seaward side of Peixe Lagoon. A-C, Aeolian deposits, showing the barchanoid dune ridge from Barrier IV (A), avalanche tongues and beetle burrows in the aeolian dunes (B), and the wet interdune deposits (C); D-E, channel deposits, clearly delimited (D) or completely recovered during flooding periods (E); $\mathbf{F}$, lagoon deposits, showing their shallowness and their large and frequently exposed margins. 


\section{THE PEIXE LAGOON PSILONICHNUS ICHNOCOENOSIS}

Two ichnocoenoses can be recognized in the seaward side of Peixe Lagoon, one subaquatic and another subaerial (Grangeiro \& Netto, 2003). The subaquatic ichnocoenosis is chiefly composed of vertical shafts and horizontal trails of polychaetes, by shallow elliptical depressions made by crabs and vertical V-shaped shafts of pelecypod siphons, when the barrier is up and the lagoon is confined. The diversity of subaquatic ichnocoenosis rises after storm surges, and stellar grazing trails of polychaetes (?Nereis) and abundant chimneys of thalassinid crustacean burrow systems can be observed. This ichnocoenosis is representative of an impoverished Cruziana Ichnofacies (sensu Pemberton \& Wightman, 1992).

The subaerial ichnocoenosis is dominantly composed of modern Psilonichnus ichnogenus produced by amphibious crabs. Invertebrate trackways and burrows, and vertebrate tracks, trackways, and burrow systems also occur. The nature of the main burrowers, the low ichnodiversity, and the presence of biogenic sedimentary structures made by scavengers (invertebrates), predators (invertebrates and vertebrates) and herbivores (vertebrates) allow its identification as a typical Psilonichnus Ichnocoenosis (Frey \& Pemberton, 1987; Pemberton et al., 1992a; Bromley, 1996; MacEachern, 2001).

Five suites can be recognized in the Psilonichnus Ichnocoenosis at Peixe Lagoon (Figure 5): (i) a lagoon edge suite, which occurs in the backbarrier zone and is dominated by short Y- and J-shaped burrows of $C$. granulata and $U$. uruguayensis; (ii) a backshore suite, which occurs in the beach side of the dune ridge and is dominated by large $\mathrm{J}$ shaped burrows of $O$. quadrata; (iii) an aeolian sand dunes suite, dominated by insect and vertebrate trackways; (iv) a wet interdune suite, dominated by insect horizontal burrows; and (v) a vegetated margin suite, dominated by multiple Ushaped burrows of $C$. granulata (Grangeiro \& Netto, 2003).

\section{The lagoon edge suite}

This suite is composed essentially of burrows excavated by mature adult crabs and shows short Y- and J-shaped dwelling burrows made respectively by $C$. granulata and $U$. uruguayensis. The J-shaped burrows of $U$. uruguayensis (Figures 6A-B) are always excavated in the limiting zone of the lagoon margins and the outer vegetated area, dominated by grass, while the Y-shaped burrows of $C$. granulata (Figures $6 \mathrm{C}$-E) are made in the bare stiffgrounds exposed between the vegetated area and the water body. The Y-shaped burrows often occur associated with thin vertical polychaete dwelling burrows and, eventually, with discrete V-shape burrows of $T$. plebeus, both belonging to the subaquatic ichnocoenosis. Such association is, in fact, a palimpsest preservation that records the seasonal oscillation of the lagoon water table level. The crab burrows usually crosscut the polychaete and pelecypod burrows, reflecting the dominance of periods of low water table, when the lagoon edges expand. The J-shaped burrows were occupied by the crab Metasesarma rubipres, a clear evidence of opportunistic behavior.

The morphological features of the crab burrows observed in the Peixe Lagoon margins allow to assignment as modern Psilonichnus and to compare the Y-shaped burrows to Psilonichnus upsilon. The depth of the main burrow observed in the $C$. granulata galleries ( $33 \mathrm{~cm}$ long on average, Figure 6D) seems to be a direct response to the dominant high water table level in the lagoon edge, which inundates the burrow's bottoms at a depth of $30 \mathrm{~cm}$ (see Figure 10), favoring branchial respiration.

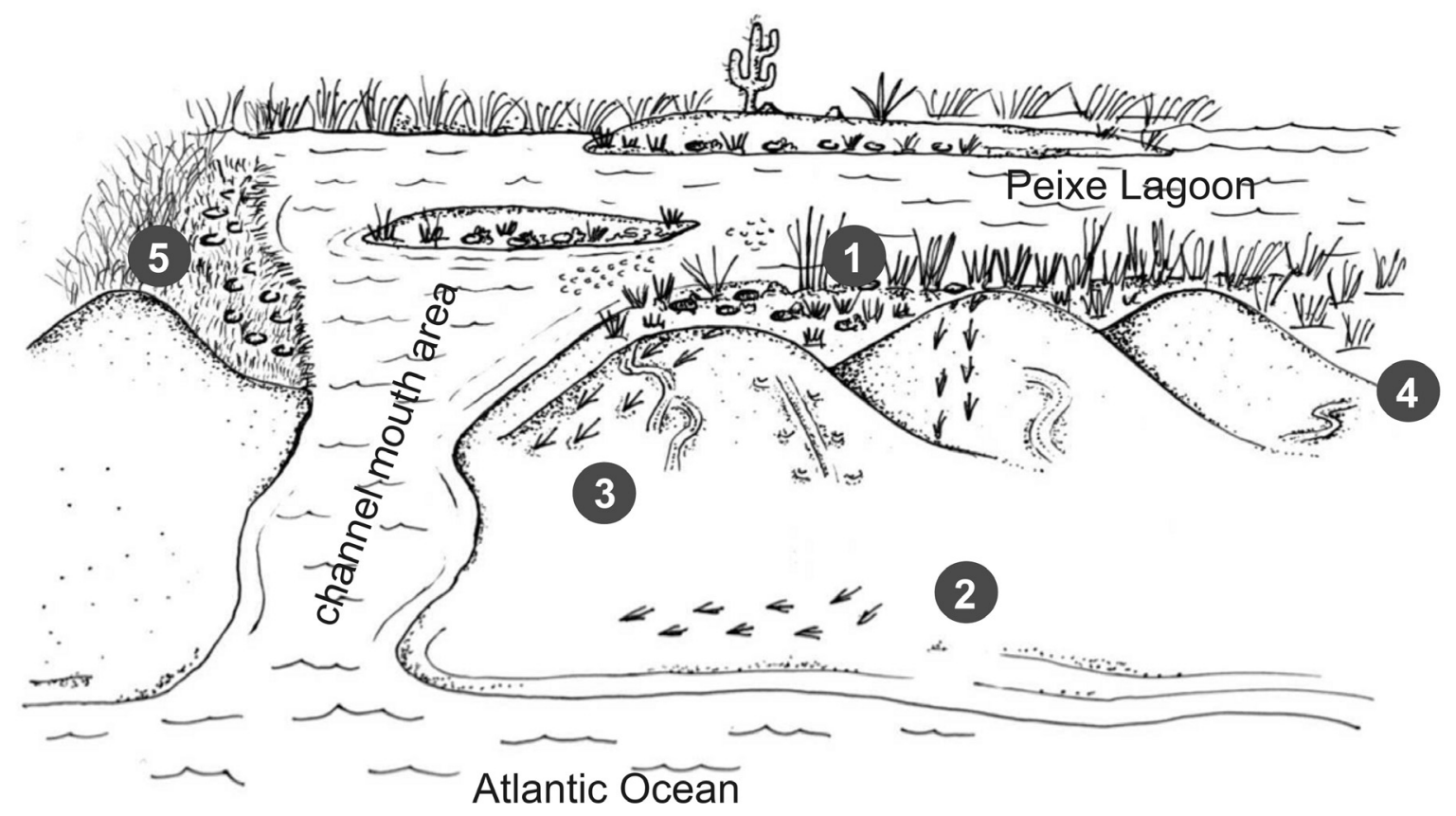

Figure 5. Distribution of the Psilonichnus ichnocoenosis suites in the study area: 1 , the lagoon edge suite; 2 , the backshore suite; 3 , the aeolian dunes suite; 4 , the wet interdune suite; 5 , the vegetated margin suite. 
Populations of $C$. granulata are more abundant than $U$. uruguayensis, resulting in a 4:1 predominance of the Yshaped burrows. The crab populations follow the lagoon base level fluctuations, colonizing the available moist substrate of the seaward side during the whole year, but hiding themselves in burrows during the winter. The Y-shaped burrows are generally occupied by a couple and extraordinarily by more than two crabs.

Avian tracks and trackways are other common biogenic structures observed in the lagoon edge suite (Figure 6F).
Most of the avifauna of Peixe Lagoon is migratory, which stop over there to feed, during the whole year, or to breed, chiefly in the southern hemisphere's springtime. Trackways are long and irregular, reflecting the animal's movements, and frequently accompanied by beak marks and open or broken shells of T. plebeus, reflecting predation of these infaunal bivalves.

\section{The backshore suite}

This suite is dominated by large inclined, J-shaped
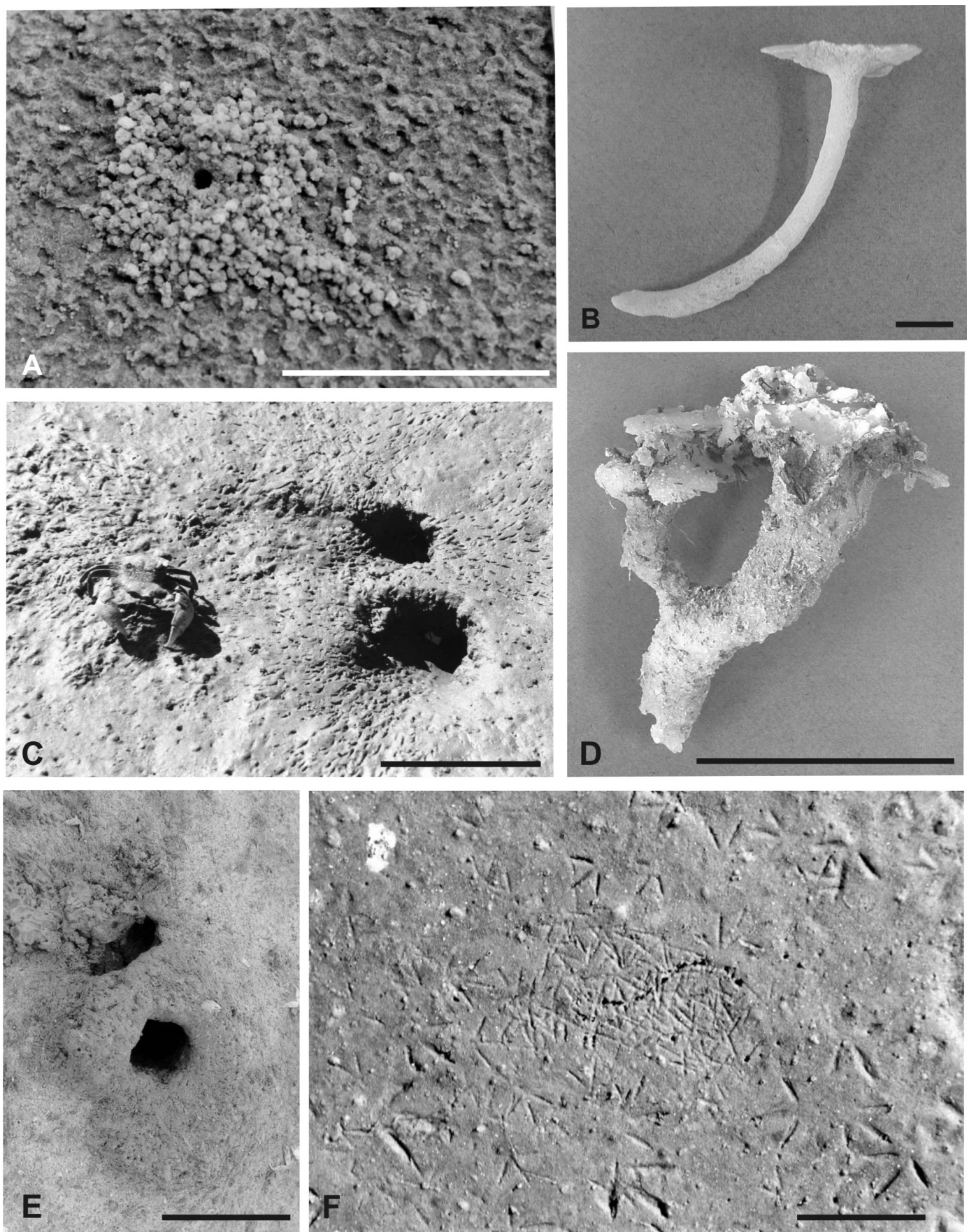

Figure 6. Biogenic sedimentary structures of the seaward side of Peixe Lagoon. A, J-shaped burrow of Uca uruguayensis with the characteristic arrangement of pellets around the burrow entrance; B, cast of $U$. uruguayensis burrow; C, E, Y-shaped burrow of Chasmagnathus granulata showing the scratch marks produced by the walking legs into and around the burrow entrance (C); D, cast of C. granulata burrow; $\mathbf{F}$, bird tracks and discrete bird trackways together with beak marks. Scale bars: $10 \mathrm{~cm}$, with exception of B (10 mm). 
burrows of Ocypode quadrata (64 cm-long, on average, Figures 7A-C), which can also be assigned to the ichnogenus Psilonichnus. O. quadrata burrows are longer than those made by amphibious crabs in the lagoon edges and do not show the Y-shaped openings. However, the main burrow morphology is equivalent to the main burrow of the P. upsilon ichnospecies. Burrows are sparsely distributed, occurring preferentially close to the seaward side of the sand dunes. Some few and discrete arthropod (insect and decapods) and mammal trackways (rodents) are also observed in this suite (Figures 7D, F).

The ichnogenus Psilonichnus has been attributed to crab activity since the study of its significance carried out by Frey et al. (1984). In spite of the reluctance of Fürsich (1981) to attribute the type-species $P$. tubiformis to crab activity, due to the incipient fossil record of these organisms in preCretaceous rocks, Frey et al. (1984) had no doubts to compare the Pleistocene Bahamian Psilonichnus upsilon with $O$. quadrata burrows. The Bahamian P. upsilon occurs in beach deposits, along the supratidal zone up to the dune barrier, being attributed to the activity of adults of $O$. quadrata (Frey et al., 1984; Curran \& White, 1991). O. quadrata is broadly distributed along the Atlantic coast from north to south Hemisphere and Gulf of Mexico as well, reaching the Rio Grande do Sul littoral (Buckup \& Bond-Buckup, 1999). In spite of Ocypode being the most "terrestrial" ocypodid decapod, their burrows are confined to the zone between the high-tide and the seaward side of the dune barrier. This fact explains the occurrence of $O$. quadrata burrows only in the backshore deposits in the study area, whilst the backbarrier Psilonichnus were produced by grapsid and fiddler crabs.

\section{The aeolian dunes suite}

This suite is dominated by insect, reptile, bird and mammal trackways and burrows. Mole cricket burrows and dune scarab beetles burrows and trackways are the most commonly observed insect biogenic structures (Figures 4B, 7E, G). Horizontal, irregularly superficial feeding burrows of mole crickets (Grilotalpidae) are frequently intercepted by bird trackways. Intersections and bifurcations are common in the mole cricket burrows, which usually show collapsed roofs (Figure 7G). Small sandy shore lizard trackways also occur, exhibiting two rows of alternate diminutive tracks separated by a medial and continuous sinusoidal groove with discrete lateral ridges (Figures 7H, I). Mammal biogenic structures are represented in the aeolian dunes suite by extensive, multichambered gallery systems excavated by small rodents of the species Ctenomys flamarioni and C. minutus.

\section{The wet interdune suite}

This suite is dominated by long, straight to sinuous shallow horizontal burrows randomly bifurcated or trifurcated made on sandy softgrounds by mole crickets (Grilotalpide) in search for food (Figure 7J). The burrow limits are well defined, but without lining. The burrow roofs are often collapsed in stiffgrounds, giving them a false bilobed aspect. In softgrounds, the mole cricket burrows show a uniform round and plain roof, with discrete external ornamentation, such as small knobs. The burrows show meniscate infill, resulting from the burrowing leg's movement (Chamberlain, 1975), and always occur in wet and moist substrates.

Irregular trackways of dune scarab beetles and other beetles are also common, composed of a continuous central shallow depression with lateral ridges, formed by abdomen dragging, and two rows of podia imprints, each one arranged parallel to the ridges, in the outer part of the trackway.

Tetradactile bird tracks of distinct sizes forming straight to curve trackways are the main vertebrate biogenic structures in the wet interdune suite.

\section{The vegetated margin suite}

This suite is dominated by multiple U-shaped burrows of C. granulata and by ant nests. The U-shaped burrows are generally found in the lagoon margins stabilized by grasses, chiefly Paspalum vaginatum. It occurs in protected areas of the seaward side of the lagoon as well as in the landward side. These U-shaped burrows consist of a broad chamber with multiple entrances (Figure $7 \mathrm{~K}$ ), inhabited by a huge amount of $C$. granulata juveniles and few adults, characterizing breeding chambers. The strategic location of these breeding chambers favors the minimum exposure of the juveniles to the open environment and, consequently, to predators, and the presence of adults in these galleries suggest parental care. Decapod breeding chambers have been reported by Curran (1976), Verde \& Martinez (2004) and Lewi \& Goldring (2006) in the fossil recorded, mostly associated with thalassinidean burrows. Recently, Genise et al. (2008) reported the occurrence of crayfish breeding burrows in Cretaceous rocks from Patagonia (Argentina), Cellicalichnus meniscatus and Dagnichinus titoi, but none of them share the same morphology observed in the $C$. granulata breeding burrows at Peixe Lagoon.

Ant nests are constructed in incipient sandy soils covered by $P$. vaginatum and the cactus Cereus sp., in the inner vegetated areas of the lateral plains and sand bars, and are completely subterraneous, not showing well-developed external mounds (Figure 7L). Unfortunately, the effort in making resin casts to evaluate the nest architecture failed.

\section{PRESERVATION POTENTIAL OF BIOGENIC SEDIMENTARY STRUCTURES IN THE PSILONICHNUS ICHNOCOENOSIS}

The seaward side of Peixe Lagoon is dynamic setting, due to the high-energy depositional processes resulting from streams, storms and winds. For this reason, the potential for preservation of most of the biogenic structures produced in this setting is low. Fluctuations in lagoon level may flood the lagoon edges, destroying partially or totally the Y-shaped crab burrows commonly present in this setting. The 
taphonomic result may be the absence of biogenic sedimentary structures or the preservation of unbranched vertical shafts, due to the destruction of the upper part of the burrows by bottom currents. Similar findings were recorded by Gingras et al. (2000) at Willapa Bay (Washington, USA).
Epigenic biogenic sedimentary structures are easily destroyed in dry environments by wind action, which reworks the sand grains, erasing the trackways in a few hours. Thus, arthropod and vertebrate trackways that form the subaerial ichnocoenosis of Peixe Lagoon have little chance of being
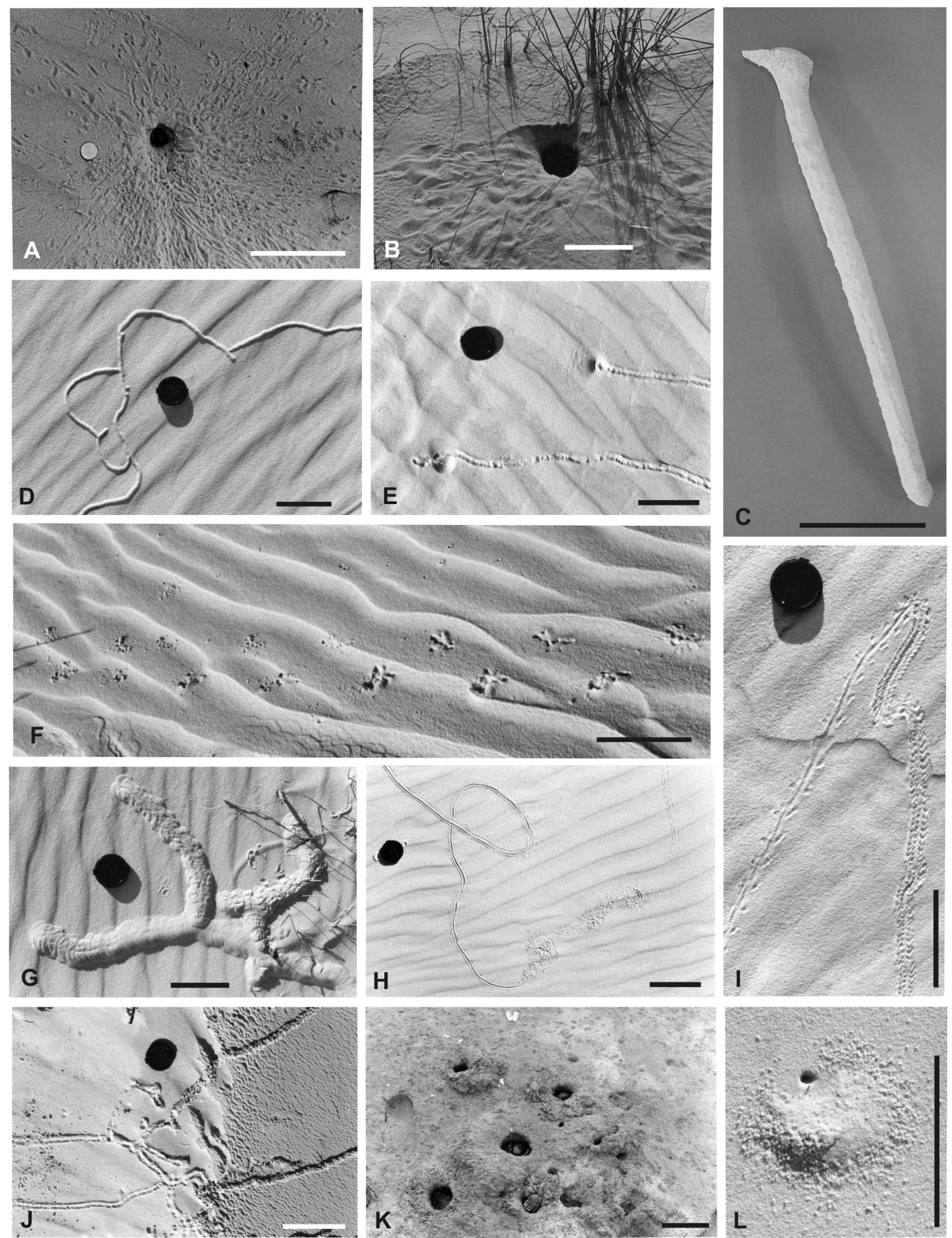

Figure 7. Biogenic sedimentary structures of the seaward side of Peixe Lagoon. A-C, Vertical burrows of Ocypode quadrata, in beach stiffgrounds, close to the aeolian dunes $(\mathbf{A})$ and in the base of the aeolian dunes (B), and its cast (C); $\mathbf{D}$, insect horizontal feeding burrow (?scarab beetle); E, scarab beetle trails departing from vertical burrows; $\mathbf{F}$, mammal trackway; $\mathbf{G}$, mole cricket complex feeding burrow; $\mathbf{H}$, a looping lizard trackway (from left top to center) going down the sand dune and the moment when the lizard trapped a beetle, going up after feeding on its prey (from center to right top); I, another meeting between a lizard and a beetle, now in horizontal, indertune sands; $\mathbf{J}$, mole cricket mosaic horizontal feeding burrows; K, multi-chambered U-shaped nesting burrows of Chasmagnatus granulata with adults patrolling the burrow entrances; L, single ant nest opening in dry sandy substrates. Biogenic sedimentary structures illustrated in A-D, F belong to the backshore suite; in E, G-I, to the aeolian dunes suite; in J, to the wet interdune suite; and in K-L, to the vegetated margin suite. Scale bars: $10 \mathrm{~cm}$. 
preserved in the fossil record. Trackways produced in wet interdune deposits, otherwise, are generally gently covered by the sand blown by the wind, having a greater preservation potential. However, the sands that fill the trackway depressions have the same composition and grain size as those forming the trackway-bearing substrate. The final result is the amalgamation of the sands after bed compaction, reducing drastically the preservation potential of the trackways in the fossil record. The taphonomic response is the little amount of bioturbation and the low ichnodiversity that is characteristic of the Psilonichnus Ichnofacies (Pemberton et al., 1992b, 1997, 2001; MacEachern, 2001; Buatois et al., 2002), in contrast with the more diverse and abundant record observed in modern Psilonichnus ichnocoenosis (Frey \& Pemberton, 1987).

The better chances of preserving tracks and trackways are in the lagoon edges and shallow bottoms, where crabs and vertebrates (especially birds) move around looking for food. The biogenic sedimentary structures produced in muddy sand substrates are recovered by clean sands blown by the wind, increasing their preservation potential. The contrast between these two deposits may be enhanced during diagenesis, favoring their observation in the fossil record. The presence of microbial mats also helps in preservation of tracks and trackways, forming a superficial resistant film that prevents desiccation and casts perfectly the biogenic structures as undertracks (Goldring \& Seilacher, 1971; Seilacher, 2008).

The biogenic structures with the highest preservation potential in the Psilonichnus ichnocoenosis at the Peixe Lagoon are the Y- and J-shaped burrows that comprise the lagoon edge suite. The stiffground nature of the substrate maintains the galleries' opening for relatively long periods, favoring their infill by different sediments and highly increasing their chances of preservation. This pattern is in accordance with the Psilonichnus Ichnofacies paradigm, originally discussed by Frey \& Pemberton (1987) and not refuted until now.

\section{STRATIGRAPHIC IMPLICATIONS}

The mix of terrestrial, quasimarine, and marine conditions of the environmental settings bearing the Psilonichnus Ichnofacies denotes its transitional character. As a consequence, the Psilonichnus ichnocoenosis is directly exposed to eustatic variations and to other phenomena related to sea level oscillations, which promote episodic, but frequent erosion of the substrates. For this reason, the preservation potential of most of the biogenic sedimentary structures that comprise the Psilonichnus ichnocoenosis is low. In the Psilonichnus ichnocoenosis at Peixe Lagoon, however, epigenic biogenic sedimentary structures are abundant and diverse, suggesting low erosion rates and relatively stable environmental conditions.
The subaquatic ichnocoenosis present in the lagoon floor (representative of the impoverished Cruziana Ichnofacies), and the lagoon edge suite of the Psilonichnus ichnocoenosis succeed each other in the studied area, creating a tiering marked by the palimpsest imprint of burrows from both assemblages, in response to water level fluctuations. Large Y-shaped burrows of $C$. granulata (lagoon edge suite) always overprint the tiny Skolithoslike vertical shafts made by polychaetes, which are the most evident structures of the subaquatic ichnocoenosis in vertical exposure. Openings of the Y-shaped burrows are generally preserved, and they are passively filled by clean, fine-grained, quartz sands showing a faint lamination. The preservation of the Y morphology and the characteristics of the infill suggest that erosional processes are rare and sedimentation rates low, allowing inference of the development of aggradational depositional cycles.

Two types of modern Psilonichnus burrows can be found in Peixe Lagoon Psilonichnus ichnocoenosis: the shorter, Y-shaped burrow produced by $C$. granulata in backbarrier settings, and the longer, faint Y-shaped burrow produced by $O$. quadrata in the beach side of the dune ridge, in the backshore zone (Figure 10). The average proportion between the burrow lengths is 1:2 and is linked to the depth of ground water level: while the freatic level is established at a depth of $30 \mathrm{~cm}$ at the lagoon edges that comprise the backbarrier deposits, in the backshore areas it occurs at a depth of around $60 \mathrm{~cm}$. Water table fluctuations have been reported as an important feature that controls the distribution of biogenic sedimentary structures in subaerial continental settings, with the position of the water table being the major factor governing the archetypical continental ichnofacies (Buatois \& Mángano, 2004, 2007; Hasiotis, 2007; Netto, 2007; Gibert \& Sáez, 2009). Therefore, the differences between burrow lengths of Psilonichnus specimens in the same ichnoassociation may be used to interpret different depths of the water table level also in marginal marine settings where the Psilonichnus Ichnofacies occurs, helping to demarcate autocyclic stratigraphic surfaces.

\section{EFFECTS OF SEA-LEVEL FLUCTUATIONS}

The Coastal Plain of Rio Grande do Sul State (PCRS) is composed of four distinct parallel, northwest-southeast oriented marine terraces formed by transgressive-regressive events, the former three representing the ancient (Pleistocene) coastlines and the fourth making up the actual coast (Tomazelli \& Villwock, 2000). The Peixe Lagoon area was flooded during the last transgressive peak ( $5 \mathrm{ka}$ ), and has been experiencing a shoaling up since them, by the dominance of progradational processes (Villwock, 1984). The environmental stability pointed out by the ichnofauna and the recurrent succession of the ichnocoenoses suggest the maintenance of the facies distribution pattern since then and allow the inference of the 
establishment of a stillstand period in the last thousand years. The equilibrium between the fluvial and marine input allows the substrate occupation by an impoverished, opportunistic marine endobenthic invertebrate fauna in the lagoon and a mixed quasimarine and non marine fauna in the surrounding settings (Figure 8).

The theoretical analysis of the stratigraphic models suggests that the sea-level fall, during the establishment of a lowstand system tract, should enhance the development of incised valleys and/or channels in the marginal marine zone, eroding most of the biogenic sedimentary structures produced during stillstand periods (Taylor \& Gawthorpe, 1993; Netto, 2001). The progradation of continental deposits should favor the development of soils in the area previously occupied by lagoons, and roots and edaphic insects should obliterate most of the previous bioturbation that could have existed. Thus, the potential of preservation of the Psilonichnus Ichnofacies record under this circumstance is minimal. A similar situation can be observed in the upper deposits of the PCRS Barrier III (Upper Pleistocene) cropping out in Osório (northern littoral of Rio Grande do Sul State) (Gibert et al., 2006).

On the contrary, transgressive events that occur in response to eustatic variations are less erosive and can preserve a good amount of the biogenic sedimentary structures produced in marginal marine settings, with little damage to the original morphology (Taylor \& Gawthrope, 1993; Netto, 2001). Thus, the Psilonichnus Ichnofacies record has a greater chance of being preserved during transgressive system tracts. Considering that the ichnofacies distribution originally extends to the backbarrier zone (Frey \& Pemberton, 1987), it is possible to propose that the stratigraphic surface developed right above the deposits bearing Psilonichnus Ichnofacies could be assumed as a ravinement surface, being, in this case, the transgressive surface or, in an extreme situation, the maximum flooding surface (Figure 9). However, if transgressive surfaces occur associated with a discrete variation in the sea level base, the complete record of the Psilonichnus Ichnofacies may be eroded or even obliterated by the development of the Skolithos Ichnofacies. This may be the case with Peixe Lagoon, where the Psilonichnus ichnocoenosis occurs at $60-70 \mathrm{~m}$ above sea level, being an easy target for marine ravinement events. In carbonate deposits, however, the potential of preservation of the Psilonichnus ichnocoenosis is higher, as early diagenesis provides sediment cohesiveness in a few months.

\section{FINAL REMARKS}

The analysis of the biogenic sedimentary structures present on the seaward side of Peixe Lagoon reveals the existence of an ichnocoenosis with the same characteristics of the assemblage originally described by Frey \& Pemberton (1987) and which served as model to define to the Psilonichnus Ichnofacies. In spite of most ancient occurrences of Psilonichnus Ichnofacies being related to backshore settings, the Psilonichnus ichnocoenosis present in the study area reinforces its extension to backbarrier settings. According to previous discussion, the preservation of the Psilonichnus ichnocoenosis of the seaward side of Peixe Lagoon in the fossil record depends on the establishment of a new transgressive system tract in the Coastal Plain of the Rio Grande do Sul State. Once preserved, the biogenic sedimentary structures of the Psilonichnus ichnocoenosis may be used as indicators of sea level changes in the PCRS, like the marine and abrasion terraces currently.

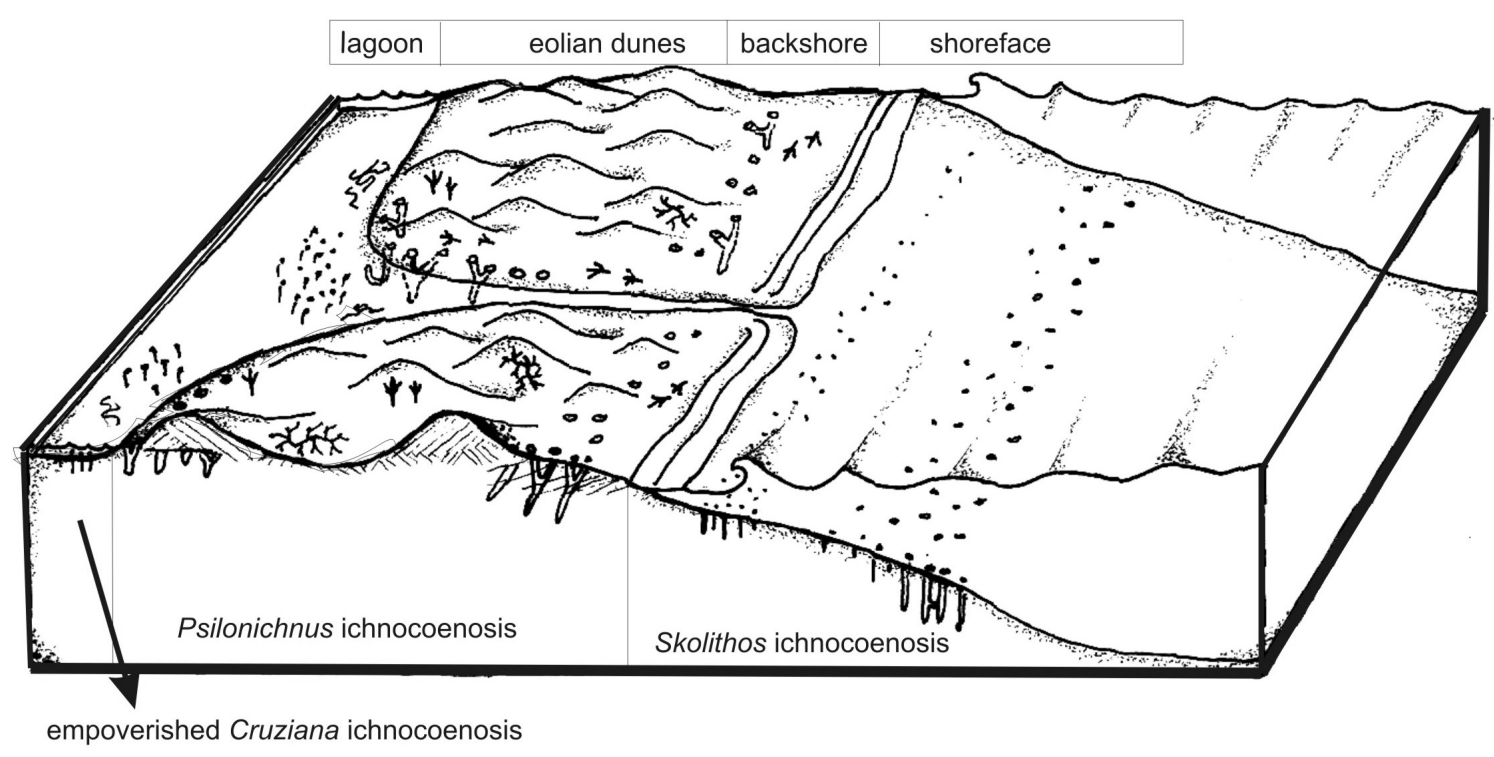

Figure 8. Schematic drawing showing the distribution of the Psilonichnus ichnocoenosis in the channel mouth area of Peixe Lagoon and its narrow relationship with the Psilonichnus Ichnofacies. 


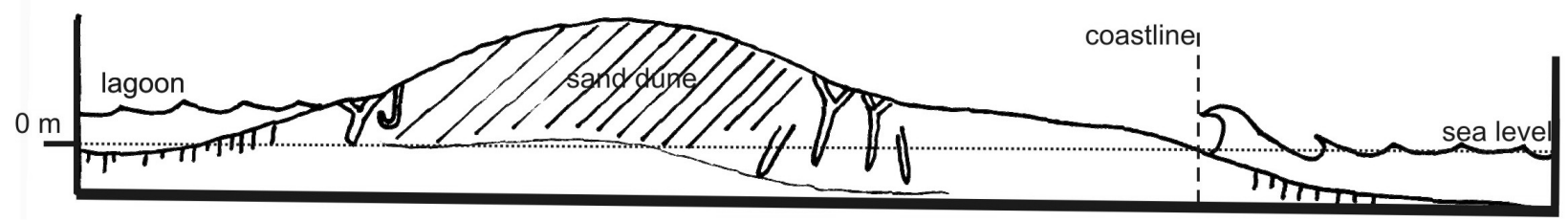

A

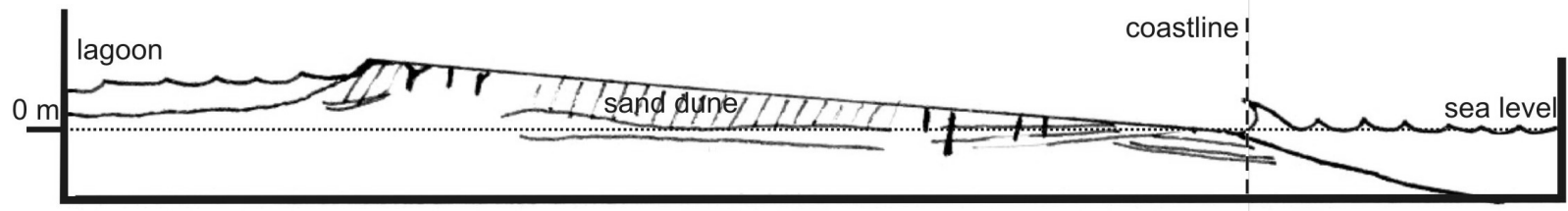

B

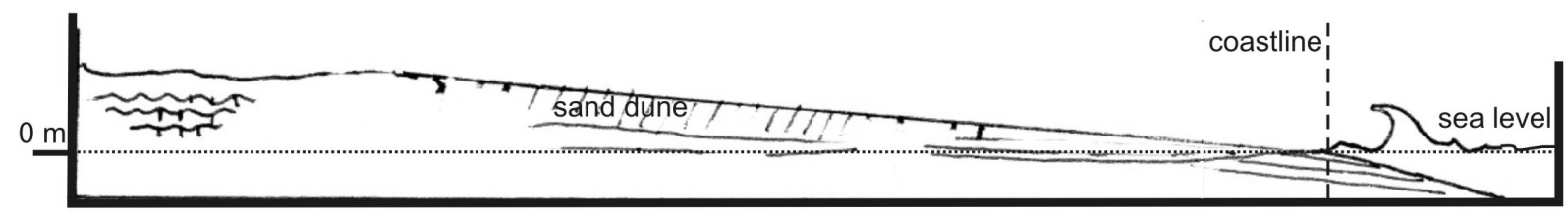

C

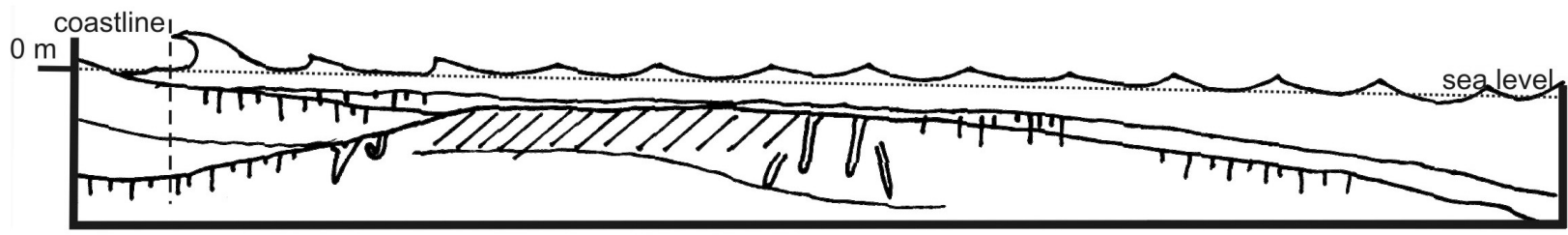

D

Figure 9. Estimated stratigraphic events and their effect on the preservation of the Psilonichnus Ichnofacies. A, actual stillstand period, in which the biogenic sedimentary structures of the Psilonichnus ichnocoenosis have been made; $\mathbf{B}$, sea-level fall and progressive erosion of the actual deposits represented in A by progradation of the continental deposits; C, final stage of the hypothetic lowstand system tract represented in $\mathrm{B}$, in which the Psilonichnus ichnocoenosis record could disappear completely; D, sea-level rise and consequent marine flooding events recovering the actual deposits represented in $\mathrm{A}$, characterizing a hypothetic transgressive system tract, which could preserve, rather than destroy, the Psilonichnus ichnocoenosis record.

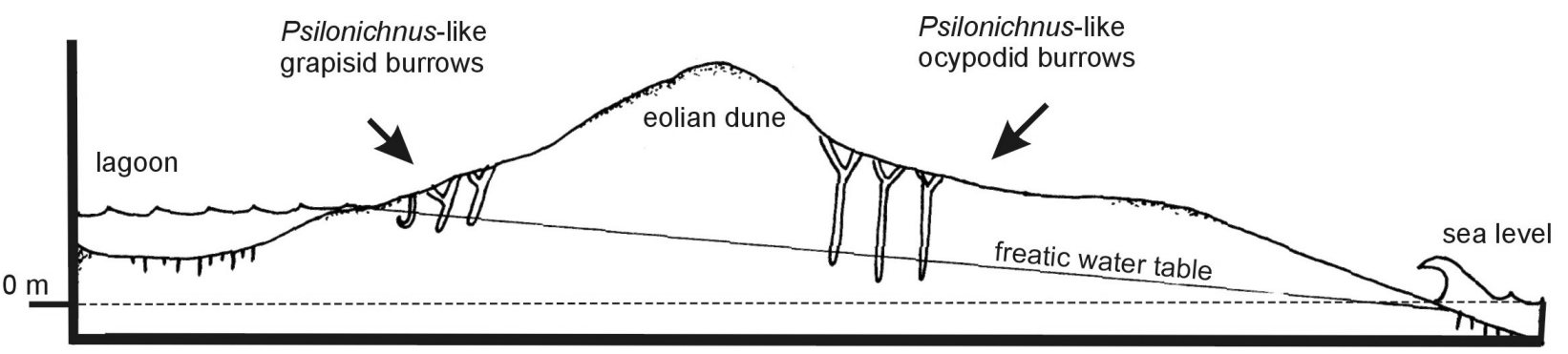

Figure 10. Schematic profile showing how the freatic water table controls the length of the Y-shaped burrows made in backbarrier ( $C$. granulata shorter burrows) and backshore (O. quadrata longer burrows) zones. 


\section{ACKNOWLEDGMENTS}

The authors thank: IBAMA, through the Peixe Lagoon National Park administration, for the research license, which allowed access to the protected areas; $\mathrm{CNPq}$, for research funds (research grants 304811/2004-1, 474345/2003-3, 303041/ 2007-2, and 479457/2007-7); and CAPES, for the graduate scholarship granted to MEG during the first years of development of this work. Drawings were originally created and drawn by MEG. The authors are also grateful to C.H. Nowatzki, E.L.C. Lavina, and R.C. Lopes, for sedimentologic discussion during field trips, M.Z. de Oliveira, for helping in field trips and in electronic edition of figures, and J.M. de Gibert, F.M.W. Tognoli, and J.R. Garrison, Jr., who critically reviewed the original manuscript, helping to improve its final version.

\section{REFERENCES}

Basan, P.B. \& Frey, R.W. 1977. Actual-palaeontology and neoichnology of salt marshes near Sapelo Island, Georgia. In: T.P. Crimes \& J.C. Harper (eds.) Trace fossils 2, Geological Journal Special Issue 9, Seel House Press, p. 41-70.

Bromley, R.G. 1996. Trace fossils. Biology, taphonomy, and applications. $2^{\mathrm{a}}$ ed., London, Chapman \& Hall, 316 p.

Bromley, R. \& Asgaard, U. 1991. Ichnofacies: a mixture of taphofacies and biofacies. Lethaia, 24:153-163.

Buatois, L.A.; Mángano, M.G. \& Aceñolaza, F.G. 2002. Trazas fósiles: señales de comportamiento en el registro estratigráfico. Trelew, Museo Paleontológico Egidio Feruglio, 382 p.

Buatois, L.A. \& Mángano, M.G. 2004. Animal-substrate interactions in freshwater environments: applications of ichnology in fácies and sequence stratigraphic analysis of fluviolacustrine successions. In: D.M. McIlroy (ed.) The applications of ichnology to palaeoenvironmental and stratigraphic analysis, Geological Society of London Special Publications, v. 228, p. 311-333.

Buatois, L.A. \& Mángano, M.G. 2007. Invertebrate ichnology of continental freshwater environments. In: W. Miller III (ed.) Trace fossils: concepts, problems, perspectives, Elsevier, p. 285-323.

Buckup, L. \& Bond-Buckup, G. 1999. Os crustáceos do Rio Grande do Sul. Porto Alegre, Editora da Universidade, UFRGS, $503 \mathrm{p}$.

Chamberlain, C.K. 1975. Recent lebensspuren in nonmarine aquatic environment. In: R.W. Frey (ed.) The study of trace fossils, Springer, p. 431-458.

Curran H.A. 1976. A trace fossil brood structure of probable callianassid origin, Journal of Paleontology, 50:249-259.

Curran, H.A. 1994. The paleobiology of ichnocoenoses in Quaternary Bahamian style carbonates environments: the modern to fossil transition. In: S.K. Donovan (ed.) The paleobiology of trace fossils, John Wiley and Sons, p. 83-104.

Curran H.A. \& White B. 1991. Trace fossils of shallow subtidal to dunal ichnofacies in Bahamian Quaternary carbonates. Palaios, 6(5):498-510.

Dashtgard, S.E. \& Gingras, M.K. 2005. The temporal significance of bioturbation in backshore deposits: Waterside Beach, New Brunswick, Canada. Palaios, 20:589-595.

De, C. 2000. Neoichnological activities of endobenthic invertebrates in downdrift coastal Ganges Delta Complex, India: their significance in trace fossil interpretations and palaeoshoreline reconstructions. Ichnos, 7(2):89-113.

Frey R.W. \& Pemberton, S.G. 1987. The Psilonichnus ichnocenosis and its relationships to adjacent marine and non marine ichnocenoses along the Georgia Coast. Bulletin of Canadian Petroleum Geology, 35(3):333-357.

Frey, R.W.; Curran, H.A. \& Pemberton, S.G. 1984. Tracemaking activities of crabs and their environmental significance: the ichnogenus Psilonichnus. Journal of Paleontology, 58(2):333-350.

Frey, R.W.; Howard, J.D. \& Hong, J.-S. 1987. Prevalent lebensspuren on a modern macrotidal flat, Inchon, Korea; ethological and environmental significance. Palaios, 2:571-593.

Frey, R.W.; Pemberton, S.G. \& Saunders, T.D.A. 1990. Icnofacies and bathymetry: a passive relationship. Journal of Paleontology, 64(1):155-158.

Fürsich, F.T. 1981. Invertebrate trace fossils from the Upper Jurassic of Portugal. Comunicações do Serviço Geológico de Portugal, 67(2):153-168.

Genise, J.F.; Bedatou, E. \& Melchor, R.N. 2008. Terrestrial crustacean breeding trace fossils from the Cretaceous of Patagonia (Argentina): palaeobiological and evolutionary significance. Palaeogeography, Palaeoclimatology, Palaeoecology, 264(1-2):128-139.

Gibert, J.M. de \& Martinell, J. 1998. El modelo de icnofácies, 30 años después. Revista Española de Paleontología, 13(2):167-174.

Gibert, J.M. de; Netto, R.G.; Tognoli, F.M.W. \& Grangeiro, M.E. 2006. Commensal worm traces and possible juvenile thalassinidean burrows associated with Ophiomorpha nodosa, Pleistocene, southern Brazil. Palaeogeography, Palaeoclimatology, Palaeoecology, 230(1-2):70-84.

Gibert, J.M. de \& Sáez, A. 2009. Paleohydrological significance of trace fossil distribution in Oligocene fluvial-fan-to-lacustrine systems of the Ebro Basin, Spain. Palaeogeography, Palaeoclimatology, Palaeoecology, 272(2009):162-175.

Gingras, M.K.; Hubbard, S.M.; Pemberton, S.G. \& Saunders, T. 2000a. The significance of Pleistocene Psilonichnus at Willapa Bay, Washington. Palaios, 15:142-151.

Gingras, M.K.; Pemberton, S.G. \& Saunders, T. 2000b. Firmness profiles associated with tidal creek deposits: the temporal significance of Glossifungites assemblages. Journal of Sedimentary Research, 70:1017-1025.

Gingras, M.K.; Pemberton, S.G. \& Saunders, T. 2001. Bathymetry, sediment texture, and substrate cohesiveness: their impact on Glossifungites trace assemblages at Willapa Bay, Washington. Palaeogeography, Palaeoclimatology, Palaeoecology, 169:1-21.

Gingras, M.K.; Pemberton, S.G.; Saunders, T. \& Clifton, H.E. 1999. The ichnology of modern and Pleistocene brackish-water deposits at Willapa Bay, Washington: variability in estuarine settings. Palaios, 14:352-374.

Gingras, M.K.; Pickerill, R. \& Pemberton, S.G. 2002. Resin casts of modern burrows provides analogs for composite trace fossils. Palaios, 17:206-211.

Gingras, M.K.; MacEachern, J.A \& Pickerill, R. 2004. Modern perspectives on Teredolites Ichnofacies: observations from Willapa Bay, Washington. Palaios, 19:79-88.

Goldring, R. \& Seilacher, A. 1971. Limulid undertracks and their sedimentologic implications, Neues Jahrbuch für Geologie und Paläontologie., Abh, 137:422-442.

Google Earth. 2009. Lagoa do Peixe, Mostardas, Rio Grande do Sul, Brazil. Available at http://www.google.earth.com/; accessed on $10 / 03 / 2009$. 
Grangeiro, M.E. \& Netto, R.G. 2003. Icnofauna de depósitos costeiros do sul do Brasil. Publicación Especial de La Asociación Paleontológica Argentina, 9:109-118.

Hauck, T.E.; Dashtgard, S.E.; Pemberton, S.G. \& Gingras, M.K. 2009. Brackish-water ichnological trends in a microtidal barrier island-embayment system, Kouchibouguac National Park, New Brunswick, Canada. Palaios, 24:478-496.

Hertweck, G. 1972. Georgia Coastal Region, Sapelo Island, USA: sedimentology and biology. V. Distribution and environmental significance of lebesspuren and in-situ skeletal remains. Senckenbergiana maritima, 4:125-167.

Howard, J.D. \& Dorjes, J. 1972. Animal-sediment relationships in two beach-related tidal flats; Sapelo Island, Georgia. Journal of Sedimentary Petrology, 42(3):608-623.

Lewi, Z. \& Goldring, R. 2006. Campanian crustacean burrow system from Israel with brood and nursery chambers representing communal organization. Paleontology, 49(1):133-140.

MacEachern, J.A. 2001. Ichnology and sedimentology in a sequence stratigraphic framework: integrated facies models for subsurface analysis. Denver, AAPG, Short Course Notes, 131 p.

Nesbitt, E.A. \& Campbell, K.A. 2006. The paleoenvironmental significance of Psilonichnus. Palaios, 21:187-196.

Netto, R.G. 2001. Paleoicnologia e estratigrafia de seqüências. In: J.H.P. Severiano Ribeiro (ed.) Estratigrafia de Seqüencias fundamentos e aplicações, Editora UNISINOS, p. 219-260.

Netto, R.G. 2007. Skolithos-dominated piperock in non-marine environments: an example from the Triassic Caturrita Formation, southern Brazil. In: R.G. Bromley; L.A. Buatois; M.G. Mángano; J.F. Genise \& R.N. Melchor (eds.) Sedimentorganism interactions: a multifaceted ichnology, SEPM Special Publication 88, p. 107-122.

Pemberton, S.G.; Frey, R.W.; Ranger, M.J. \& MacEachern, J. 1992a. The conceptual framework of Ichnology. In: S.G. Pemberton (org.) Applications of ichnology to petroleum exploration, SEPM Core Workshop 17, p. 1-32.

Pemberton, S.G.; MacEachern, J. \& Frey, R.W. 1992b. Trace fossils facies models. Environmental and allostratigraphic significance. In: R.G. Walker \& N.P. James (eds.) Facies models - response to sea level change, Geological Association of Canada, p. 47-72.

Pemberton, S.G.; MacEachern, J.A. \& Buatois, L.A. 1997. Criterios icnológicos para el reconocimiento y la interpretación de discontinuidades erosivas. Boletin de la Sociedad Venezoelana de Geólogos, 22(1):7-32.

Pemberton, S.G.; Spilla, M.; Pulham, A.J.; Saunders, T.; MacEachern, J.A.; Robbins, D. \& Sinclair, I.K. 2001. Ichnology and sedimentology of shallow to marginal marine systems: Ben Nevis and Avalon reservoirs, Jeanne d'Arc Basin. Calgary, Geological Association of Canada, Short Course Notes 15, 343 p.

Pemberton, S.G. \& Wightman, D.M. 1992. Ichnological characteristics of brackish water deposits. In: S.G. Pemberton (org.) Applications of ichnology to petroleum exploration, SEPM Core Workshop 17, p. 141-168.

Seilacher, A. 2008. Biomats, biofilms, and bioglue as preservational agents for arthropod trackways. Palaeogeography, Palaeoclimatology, Palaeoecology, 270(3-4):252-257.

Taylor, A.M. \& Gawthorpe, R.L. 1993. Applications of sequence stratigraphy and trace fossil analysis to reservoir description: examples from Jurassic of the North Sea. In: J.R. Parker (ed.) Petroleum geology of Northwest Europe: proceedings of the 4th conference, The Geological Society of London, p. 317-335.

Tomazelli, L.J. \& Villwock, J.A. 2000. O Cenozóico do Rio Grande do Sul: geologia da planície costeira. In: M. Holz \& L.F. De Ros (eds.) Geologia do Rio Grande do Sul, CIGO/UFRGS, p. 375-406.

Verde, M. \& Martínez, S. 2004. A new ichnogenus for crustacean trace fossils from the Upper Miocene Camacho Formation of Uruguay. Paleontology, 47(1):39-49.

Villwock, J.A. 1984. Geology of the coastal province of Rio Grande do Sul, Southern Brazil. Pesquisas, 16:5-49.

Villwock, J.A.; Tomazelli, L.J.; Loss, E.L.; Dehnhardt, E.A.; Horn, N.O.; Bachi, F.A. \& Dehnhardt, B.A. 1986. Geology of the Rio Grande do Sul Coastal Province. In: J. Rabassa (ed.) Quaternary of South America and Antarctic Peninsula. A.A. Balkema, v. 4, p. 79-97.

White, B. \& Curran, H.A. 1993. Sedimentology and ichnology of Holocene dune and backshore deposits, Lee Stocking Island, Bahamas. In: Symposium on the Geology of the Bahamas, 6, 1993. Proceedings, San Salvador, Bahamian Field Station, p. 181-191.

Received in May, 2009; accepted in November, 2009. 